\title{
Skin lesion in a patient with Hirschsprung's disease complicated with short bowel syndrome: what is your diagnosis?
}

\author{
Chi-Hone Lien, ${ }^{1}$ Yu-Ling Lin, ${ }^{2}$ Sung-Tse Li, ${ }^{1}$ Chien-Yu Lin ${ }^{1}$ \\ ${ }^{1}$ Department of Paediatrics, Hsinchu Mackay Memorial Hospital, Hsinchu, Taiwan \\ ${ }^{2}$ Department of Nutrition, Hsinchu Mackay Memorial Hospital, Hsinchu, Taiwan \\ Correspondence to Dr Chien-Yu Lin, mmhped.lin@gmail.com
}

\section{DESCRIPTION}

A 13-year-old boy with Hirschsprung's disease complicated with intestinal-cutaneous fistula, short bowel syndrome and malnutrition presented to our hospital after thirst and decrease of urine output for 3 days. He had received primary laparoscopy-assisted endorectal pullthrough (LAERPT) for Hirschsprung's disease when he was 4 months old, but he had performed eight more operations for complications, resulting in loss of the majority of small and large bowels. Initial evaluation revealed tachycardia (heart rate, 136 beats per minute), hyponatremia, hypocalcaemia and hypoalbuminaemia (serum sodium $127 \mathrm{mmol} / \mathrm{l}$, calcium $1.6 \mathrm{mmol} / \mathrm{l}$, albumin $19 \mathrm{~g} / \mathrm{l}$ ). Diffuse bullous, pustular skin lesion with weeping desquamation was inspected as well, predominantly located in scalp, hands, feet, skin flexures and periocular, perioral, perianal areas (figure 1). The skin was dry and the eruption was itchy. What is your diagnosis?

The skin lesion was suggestive of zinc deficiency and the serum zinc level was $4.896 \mu \mathrm{mol} / 1$ (normal range: $10.71-18.36 \mu \mathrm{mol} / \mathrm{l})$. Zinc deficiency secondary to reduced intake, mal-absorption and high ostomy output due to short bowel syndrome was suspected. His family refused skin biopsy and the supplement of zinc was initiated. His skin lesion had improved after zinc supplement in addition to his customary replacement for short bowel syndrome, and the diagnosis was established.
Zinc deficiency is rare in Taiwan and is easily neglected. The characteristic skin lesion is indicative of zinc deficiency and a high index of suspicion should be maintained in malnourished children and children with short bowel syndrome. ${ }^{1}$ Early recognition of zinc deficiency and timely supplement is important for primary healthcare providers.

\section{Learning points}

Zinc deficiency is rare in developed countries. We have to maintain alertness of zinc deficiency in patients with short bowel syndromes.

- The skin lesion of zinc deficiency dermatitis is impressive and characteristic, which is indicative of zinc deficiency. Being familiar with this presentation helps us to make an early diagnosis of zinc deficiency.

Competing interests None.

Patient consent Obtained.

\section{REFERENCE}

1. Jose FA, Heyman MB. Extraintestinal manifestations of inflammatory bowel disease. J Pediatr Gastroenterol Nutr 2008;46:124-33.

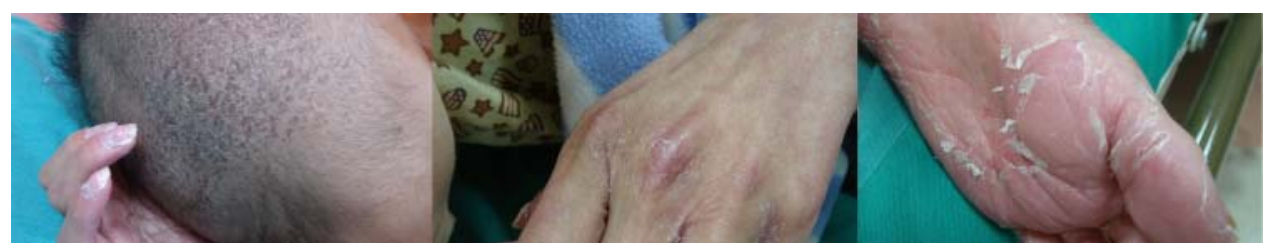

Figure 1 Diffuse bullous, pustular skin lesion with weeping desquamation were noted over scalp, hands and feet. 


\section{BMJ Case Reports}

This pdf has been created automatically from the final edited text and images.

Copyright 2012 BMJ Publishing Group. All rights reserved. For permission to reuse any of this content visit http://group.bmj.com/group/rights-licensing/permissions.

BMJ Case Report Fellows may re-use this article for personal use and teaching without any further permission.

Please cite this article as follows (you will need to access the article online to obtain the date of publication).

Lien C-H, Lin Y-L, Li S-T, Lin C-Y. Skin lesion in a patient with Hirschsprung's disease complicated with short bowel syndrome: what is your diagnosis? BMJ Case Reports 2012;10.1136/bcr-03-2012-6078, Published XXX

Become a Fellow of BMJ Case Reports today and you can:

- Submit as many cases as you like

- Enjoy fast sympathetic peer review and rapid publication of accepted articles

- Access all the published articles

- Re-use any of the published material for personal use and teaching without further permission

For information on Institutional Fellowships contact consortiasales@bmjgroup.com

Visit casereports.bmj.com for more articles like this and to become a Fellow 